\title{
Development and evaluation of nutritionally enhanced potato rice papads (Indian cookie)
}

\section{Sukhpreet Kaur* and Poonam Aggarwal}

Department of Food Science and Technology, Punjab Agricultural University, Ludhiana-141004 (Punjab), INDIA *Corresponding author. E-mail: sukhpreetnagra1@gmail.com

Received: January 7, 2015; Revised received: March 20, 2015; Accepted: April 10, 2015

\begin{abstract}
The present study was carried out to develop papads (Indian cookie) from potato (Solanum tuberosum L.) and rice (Oryza sativa) blends and to analyze them for organoleptic, physicochemical, phytochemical and shelf life quality. Two processing cultivars (Kufri Chipsona-1, Kufri Chandramukhi) and one commonly grown cultivar (Kufri Pukhraj) were evaluated for processing into papad. Based on preliminary sensory trails, papads with boiled potato mash $(60 \%)$ and gelatinized rice $(30 \%)$ level of supplementation were found to be most acceptable and these papads were subjected to nutritional evaluation. Results were compared with rice papads (control). Protein content and yield was significantly $(p<0.05)$ higher in control papads compared to potato supplemented papads. Oil uptake significantly $(p<0.05)$ increased on supplementation with potato. Bioactive compounds including ascorbic acid, total phenolics and total antioxidant activity measured as DPPH radical scavenging activity increased significantly $(p<0.05)$ on incorporation of potato. Between the cultivars, papads enriched with Kufri Pukhraj, a table variety which is considered unfit for processing, displayed the highest phytochemical content and total antioxidant activity. Sensory evaluation indicated higher overall acceptability scores of potato enriched papads compared to control. During storage of papads at room temperature for up to 3 months, significant $(p<0.05)$ changes in the moisture content, phytochemical content and antioxidant activity were observed. Storage studies showed that the potato supplemented papads can be stored safely for 3 months of storage at ambient temperature.
\end{abstract}

Keywords: Antioxidant activity, Oil uptake, Papads, Phytochemicals, Potato

\section{INTRODUCTION}

Potato (Solanum tuberosum L.) is one of the most widely consumed tubers in many cuisines. Potato is notably recognized as a source of high quality proteins, carbohydrates, vitamin $\mathrm{C}$, vitamin $\mathrm{B}_{6}$ and certain minerals such as potassium, phosphorous and magnesium (Gumul et al., 2011). Beyond these basic nutrients, potato tubers present a very significant source of antioxidant phytochemicals such as anthocyanins, phenolics and vitamin $\mathrm{C}$ which are highly desirable in diet because of their beneficial effect on human health (Lachman and Hamouz, 2005; Ezekiel et al., 2013).

India became the second largest producer of potato in the world with bumper crop of 41.48 million tonnes in the year 2012-13 (Saxena and Mathur, 2013). Potato (Solanum tuberosum L.) is one of the commonly used vegetable and is staple diet for a large number of people in the world but main disadvantage of the crop is that it is seasonal and bulky production of crop has short life. Lack of sufficient storage facilities result in crop deterioration as post harvest time advances (Misra and Kulshrestha, 2003).

Dehydration of bumper perishable crop seems to be convenient alternative for long term storage and could serve as means to ensure availability of potatoes in different forms throughout the year. Potato can be processed into an indigenous dehydrated product called papad (Indian cookies), which has a promising future due to its long shelf life and diverse uses. Papad also known as Appalam is a popular snack item in India. A variety of papads are available in India, which are produced from a great diversity of ingredients. Usually, they are made either using only cereal flour or a combination of pulse flour with salt, spices and some additives (Garg and Dahiya, 2003). The demand for papad is rising rapidly both in country and abroad. So, there is greater scope for introduction of varieties of papads prepared from cost effective raw ingredients.

Since production of potato is abundant, there is a need to find diversified uses in order to maximize their utilization and to cater the fast changing taste of new generation. Potato processing has considerable potential to reduce post-harvest losses and to generate income through the manufacture of value-added food products. Thus, the aim of this work was to develop papads enriched with different potato ( $S$. tuberosum L.) cultivars and to evaluate the quality characteristics of the developed product in order to assess its physicochemical, phytochemical and shelf life properties.

\section{MATERIALS AND METHODS}

Raw materials: Two potato cultivars known for better quality characteristics (Kufri Chipsona-1, Kufri 
Chandramukhi) and one commonly cultivated variety (Kufri Pukhraj) were procured from Vegetable Crops Department of the Punjab Agricultural University and were used for production of papads. Rice flour from broken kernels, salt, sodium bicarbonate (papad khar) and spices (cumin seeds, carom seeds, black pepper) were purchased locally. Frying was done with refined soybean oil and was purchased locally.

\section{Preparation of raw materials}

Boiled potato mash: Fresh potato tubers $(1 \mathrm{~kg})$ of each cultivar were washed, peeled, cut into four quarters and pressure cooked in water $(1 \mathrm{~L})$ for $5 \mathrm{~min}$. The boiled potatoes were cooled and mashed.

Gelatinized rice flour: Rice flour (500 g) from broken kernels was sieved and then poured to boiling water (1L) containing $0.5 \%$ papad khar and cooked for 3-5 minutes for complete gelatinization and then cooled to room temperature.

Formulation of potato rice papad: Potato rice papads were formulated by incorporating potato in different proportions. Proportions of ingredients which were liked best sensorily were selected for the development of final product. Potato mash was blended with gelatinized rice flour in the ratio 0:100 (control), 20:80, 40:60, $60: 40$ and $80: 20$. Based on preliminary sensory trials, substitution of up to $60 \%$ of potato produced significant desirable changes in the sensory characteristics of fried papads. So, this level was used for the preparation of the final product.

Processing method: For making papad, freshly prepared potato mash $(60 \mathrm{~g})$ was blended thoroughly with gelatinized rice flour $(40 \mathrm{~g})$, cumin $(0.3 \mathrm{~g})$, black pepper $(0.1 \mathrm{~g})$, carom seeds $(0.2 \mathrm{~g})$ and salt $(2 \mathrm{~g})$ and kneaded uniformly to prepare soft dough. Dough was divided into small balls (20 g each). The dough balls were put on oil smeared polythene sheets and were pressed into thin ( $1 \mathrm{~mm}$ thick) papad sheets using a manual papad making machine. These papad sheets were then dried in hot air cabinet dryer at $40 \pm 5^{\circ} \mathrm{C}$ for 8 hours.

Physicochemical analysis: The moisture, protein and ash contents of the raw materials and powdered papad samples were determined by official methods (AOAC, 2005). Reducing sugars of raw potato tubers were determined by the Nelson Somogyi method (Pearson, 1976). Oil uptake of fried papads was measured using soxhlet extraction method (Ranganna, 2004). Yield was calculated after frying the papads.

Phytochemical analysis : In the raw material and prepared papads, the ascorbic acid content, total phenolic content and antioxidant activity as DPPH radical scavenging activity was also determined.

The ascorbic acid content was determined by visual titration method using 2, 4-Dichlorophenol-Indophenol dye method (Ranganna, 2004). The results were expressed as milligram of ascorbic acid/100 g dw. Phenolic compounds were extracted from sample ( $5 \mathrm{~g}$ fresh tissue; $1 \mathrm{~g}$ dry ingredient) according to Velioglu et al. (2009) with 50 $\mathrm{ml}$ of $80 \%(\mathrm{v} / \mathrm{v})$ aqueous methanol for 3 hours at $40^{\circ} \mathrm{C}$ with refluxing. The content of total phenolic compounds in extract was determined using the Folin-Ciocalteu's colorimetric method (Velioglu et al..2 2009). The absorbance at $765 \mathrm{~nm}$ was measured after $30 \mathrm{~min}$ and the results were expressed as gallic acid equivalents (mg GAE/100 g dw).

The antioxidant activity of aqueous extracts of raw materials and papads was determined using 1,1 -diphenyl-2-picrylhydrazyl (DPPH) radical. The ability of the prepared extracts to scavenge the stable free radical was estimated using the method of Yamaguchi et al. (1998). Methanolic extract of sample was taken for antioxidant activity and calculated according to the following formula. BHT was taken as a standard at a fixed concentration of $5 \mathrm{mg} / \mathrm{ml}$.

Radical scavenging activity $(\%)=$ Absorbance of control (0 minute) - Absorbance of sample (30 minute)

Absorbance of control ( 0 minute) x 100

Texture Analysis of fried papads: Hardness of fried papads was determined by the texture analyzer (LLOYD texture instrument LR 5K, England) with an aluminium circular probe of $70 \mathrm{~mm}$ of diameter and a test speed of $1 \mathrm{~mm} / \mathrm{s}$. The thresholds of force and distance were $1 \mathrm{~g}$ and $1 \mathrm{~mm}$, respectively. Ten measurements were taken. Papads were placed on the crisp fracture support rig (code TA-101) and the circular probe was allowed to penetrate the snacks. Hardness (g) was recorded as the maximum force required for breaking the papad into two pieces.

Sensory quality evaluation: Papads (after frying at $175^{\circ} \mathrm{C}$ for $30 \mathrm{sec}$ ) were evaluated by a panel of 10 judges using 9-point Hedonic scale for their sensory characteristics like appearance, flavor, texture and overall acceptability. The scores were assigned from extremely liked (9) to disliked extremely (1).

Storage studies: Papads were packed in 200 gauge polythene bags and sealed in tight air containers. The packed papads were exposed to room temperature (26-38 $\left.{ }^{\circ} \mathrm{C} / \mathrm{RH} 35-87 \%\right)$ for a period of 3 months. Storage stability of the product was assessed by determining the changes in moisture, bioactive composition and antioxidant activity. Sensorial analysis of the stored papads was done by a semi trained panel of 10 judges using 9-point Hedonic scale.

Statistical analysis: All the experiments were carried out in triplicate. One-way analysis of variance was performed using the SPSS version 20.0 (Statistical Package for Social Sciences). Significant differences $(\mathrm{p}<0.05)$ were determined by Tukey's.

\section{RESULTS AND DISCUSSION}

\section{Quality characteristics of fresh papads}

Physicochemical attributes: The physicochemical characteristics of control papads and potato incorporated papads are summarized in table 2 . Significant $(\mathrm{p}<$ 0.05 ) differences were found in the moisture content of control and supplemented papads. The moisture content of control papads was $8.34 \%$ and that of 
Sukhpreet Kaur and Poonam Aggarwal / J. Appl. \& Nat. Sci. 7 (1) : 242 - 248 (2015)
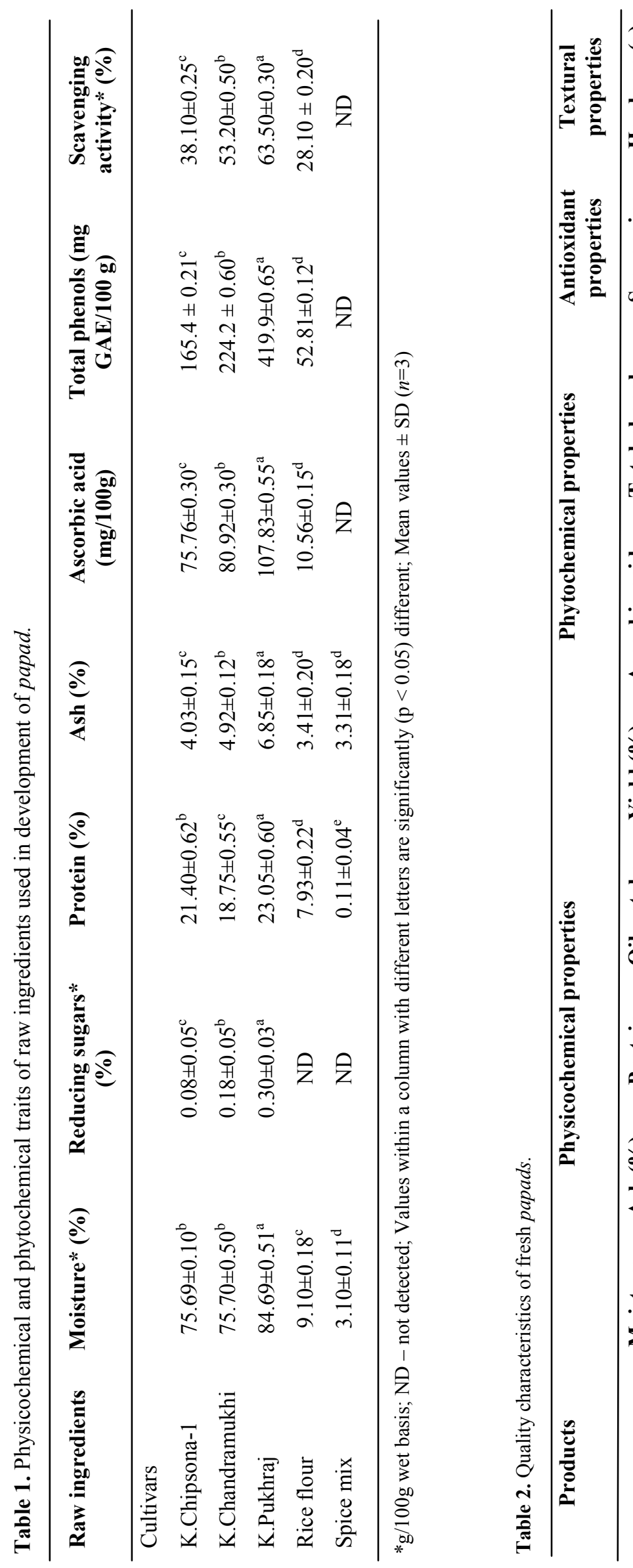

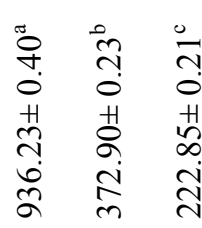

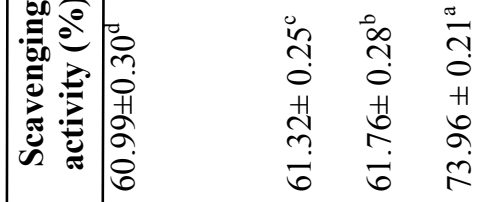

응

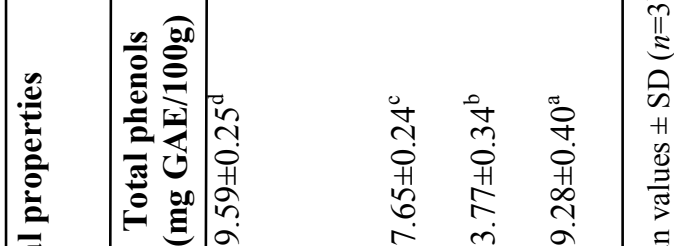

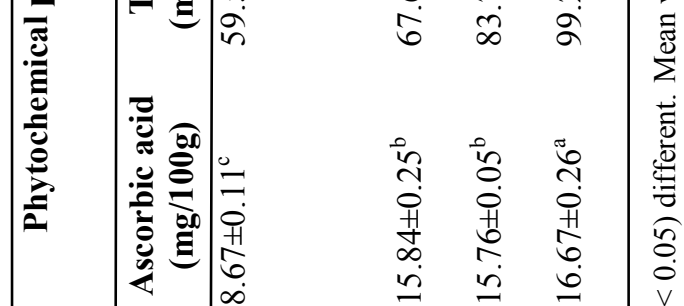

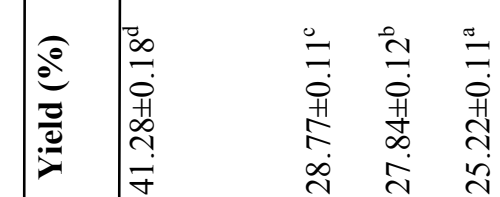

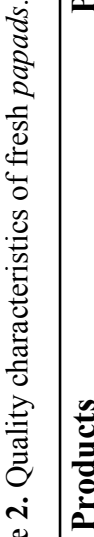

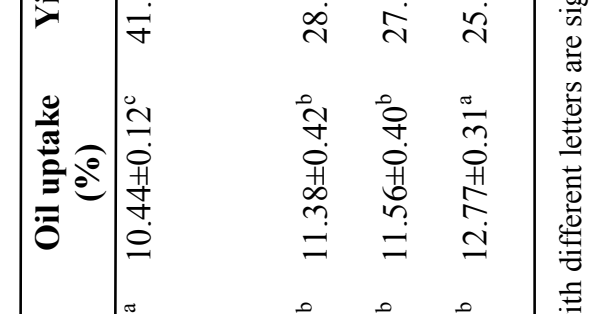

|

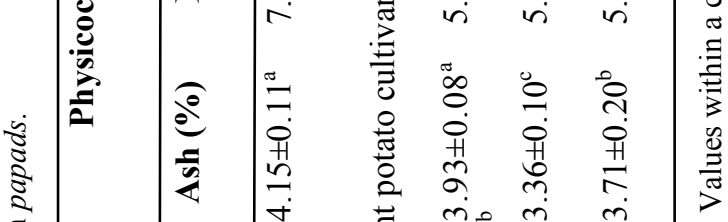


Table 3. Effect of frying on phytochemical content and antioxidant activity of raw papads.

\begin{tabular}{|c|c|c|c|c|c|c|}
\hline \multirow[t]{2}{*}{ Product } & \multicolumn{2}{|c|}{ Ascorbic acid } & \multicolumn{2}{|c|}{ Total phenolic content } & \multicolumn{2}{|c|}{ Antioxidant activity } \\
\hline & Raw & fried & Raw & fried & Raw & fried \\
\hline $\begin{array}{l}\text { Control } \\
\text { (without } \\
\text { potato) } \\
\text { Panads sunnle }\end{array}$ & $8.67 \pm 0.11^{\mathrm{c}}$ & $6.31 \pm 0.10^{\mathrm{c}}$ & $59.59 \pm 0.25^{d}$ & $53.41 \pm 0.29^{\mathrm{c}}$ & $57.01 \pm 0.30^{\mathrm{d}}$ & $55.27 \pm 0.21^{b}$ \\
\hline K.Chipsona-1 & $15.84 \pm 0.25^{\mathrm{b}}$ & $13.35 \pm 0.11^{\mathrm{a}}$ & $67.65 \pm 0.24^{\mathrm{c}}$ & $51.33 \pm 0.28^{\mathrm{d}}$ & $57.82 \pm 0.25^{\mathrm{c}}$ & $55.0 \pm 0.30^{\mathrm{c}}$ \\
\hline $\begin{array}{l}\text { K. Chandra- } \\
\text { mukhi }\end{array}$ & $15.76 \pm 0.05^{\mathrm{b}}$ & $12.11 \pm 0.15^{b}$ & $83.77 \pm 0.34^{b}$ & $79.21 \pm 0.30^{\mathrm{b}}$ & $58.13 \pm 0.28^{b}$ & $54.14 \pm 0.20^{\mathrm{d}}$ \\
\hline K.Pukhraj & $16.67 \pm 0.26^{\mathrm{a}}$ & $12.26 \pm 0.11^{\mathrm{b}}$ & $99.28 \pm 0.40^{\mathrm{a}}$ & $95.42 \pm 0.45^{\mathrm{a}}$ & $70.12 \pm 0.21^{\mathrm{a}}$ & $65.0 \pm 0.28^{\mathrm{a}}$ \\
\hline
\end{tabular}

*Results expressed on dry weight basis. Values within a column with different letters are significantly $(\mathrm{p}<0.05)$ different. Mean values $\pm \mathrm{SD}(n=3)$.

supplemented ones in the range of $5.40-5.53 \%$. The ash content of control papads was $4.15 \%$ and it ranged from 3.36 to $3.93 \%$ in potato supplemented papads (Table 2). This might be due to their compositional differences. In control papads, protein content was $7.04 \%$ that was found to be significantly $(\mathrm{p}<0.05)$ higher than that of potato supplemented papads $(5.37$ $-5.43 \%$ ) (Table 2 ). There was a wide variation in the oil absorption and yield of fried papads. Oil uptake of potato incorporated papads (11.38-12.77\%) was found to be significantly $(\mathrm{p}<0.05)$ higher than that of control papads $(10.44 \%)$ (Table 2$)$. Yield was significantly higher in control papads compared to potato incorporated papads. Between the cultivars studied, papads supplemented with K.Pukhraj showed higher absorption of oil and lower yield compared to K.Chipsona-1 and K. Chandramukhi supplemented papads. This might be due to differences in their dry matter content. The dry matter content in fresh tubers of cultivars K. Chipsona-1, K.Chandramukhi and K.Pukhraj was 24.31, 24.30 and 15.31 per cent, respectively. K.Pukhraj with its lower dry matter content can be expected to show higher oil uptake and lower yield while K.Chipsona-1 and K.Chandramukhi with higher dry matter content showed lower oil uptake and higher yield. Tuber dry matter content is known to be positively correlated with mealiness and higher yield (Ramezani and Aminlari, 2004) and negatively correlated with oil uptake in fried potato products (Kaur et al., 2009; Marwaha et al., 2010).

Phytochemical attributes: Phytochemical attributes i.e. ascorbic acid and total phenolic content and antioxidant activities measured as DPPH radical scavenging activities of fresh papads significantly $(\mathrm{p}<0.05)$ increased on supplementation with potato as compared to control papads (Table 2). It might be due to a larger amount of phytochemical content in potato in comparison to rice flour (Table 1). Between the cultivars studied, papads supplemented with K.Pukhraj had the highest bioactive content and antioxidant activity while lowest was observed in K.Chipsona-1 papads (Table 2). The higher concentration of these phytochemicals in $\mathrm{K}$. Pukhraj at initial level (Table 1) might have contributed towards their higher retention in the prepared product.

Textural attributes: As for texture, it was found that hardness of papads supplemented with K.Chipsona-1 and K.Chandramukhi was significantly $(\mathrm{p}<0.05)$ higher than that prepared from K.Pukhraj (Table 3). Papads prepared from K.Pukhraj was comparatively soft and crisp whereas those prepared from K.Chipsona-1 were less crispy and hard in texture. This might be due to high dry matter and low moisture content in 'K.Chipsona-1'.

\section{Storage studies}

Moisture content: Since papads are dehydrated products, there preservation depends upon their moisture content, which should be low enough to prevent the growth of microorganisms. In the present study, there was a gradual increase $(\mathrm{p}<0.05)$ in the moisture content of potato supplemented papads during storage, irrespective of cultivars (Fig. 1). The average moisture content of papads increased from 5.45 to $6.14 \%$ during 3 months of storage. This might be due to variation in atmospheric relative humidity $(\mathrm{RH})$, which ranged from $35-85 \%$ during the storage period. Similar behaviour was also observed in cereal based papads (Puyed and Prakash, 2008; Veena et al., 2012) and in dehydrated jackfruit papads (Jagadeesh et al., 2007) stored at room temperature for 180 days.

Phytochemical content and antioxidant activity: The plant foods are known for their phytochemical content and antioxidant characteristics; therefore, it is essential to investigate the influence of storage and processing on these bioactive food components.

During storage, the mean ascorbic acid content of potato supplemented papads was found to be decreased from original value, regardless of the cultivars (Fig. 2a). The initial mean ascorbic acid content of potato rice papads was $16.09 \mathrm{mg} / 100 \mathrm{~g} \mathrm{dw}$, which decreased $(\mathrm{p}<0.05)$ consistently to $13.30 \mathrm{mg} / 100 \mathrm{~g} \mathrm{dw}$, after 3 months of storage. This might be due to oxidation of the thermoliabile ascorbic acid into dehydroascorbic acid upon storage 
Table 4. Effect of storage on sensory quality of papads.

\begin{tabular}{|c|c|c|c|c|}
\hline \multirow[t]{2}{*}{ Product } & \multicolumn{2}{|c|}{ Duration of storage (months) } & \multirow[b]{2}{*}{2} & \multirow[b]{2}{*}{3} \\
\hline & $\mathbf{0}$ & 1 & & \\
\hline \multicolumn{5}{|c|}{ Appearance } \\
\hline Control (without potato) & $7.53 \pm 0.03^{\mathrm{cA}}$ & $7.50 \pm 0.03^{\mathrm{dA}}$ & $7.55 \pm 0.03^{\mathrm{bA}}$ & $7.50 \pm 0.03^{\mathrm{bB}}$ \\
\hline \multicolumn{5}{|c|}{ Papads supplemented with different potato cultivars } \\
\hline K.Chipsona-1 & $8.25 \pm 0.01^{\mathrm{aA}}$ & $8.20 \pm 0.05^{\mathrm{aB}}$ & $8.21 \pm 0.05^{\mathrm{bB}}$ & $8.25 \pm 0.03^{\mathrm{aA}}$ \\
\hline K. Chandramukhi & $8.23 \pm 0.04^{\mathrm{aA}}$ & $8.13 \pm 0.02^{\mathrm{bA}}$ & $8.20 \pm 0.02^{\mathrm{aB}}$ & $8.24 \pm 0.05^{\mathrm{aA}}$ \\
\hline K.Pukhraj & $7.62 \pm 0.03^{\mathrm{bA}}$ & $7.60 \pm 0.03^{\mathrm{cA}}$ & $7.55 \pm 0.02^{\mathrm{aC}}$ & $7.50 \pm 0.01^{\mathrm{bD}}$ \\
\hline \multicolumn{5}{|c|}{ Flavor } \\
\hline Control (without potato) & $7.16 \pm 0.03^{\mathrm{cA}}$ & $7.18 \pm 0.03^{\mathrm{bA}}$ & $7.10 \pm 0.03^{\mathrm{bB}}$ & $7.10 \pm 0.05^{\mathrm{cB}}$ \\
\hline \multicolumn{5}{|c|}{ Papads supplemented with different potato cultivars } \\
\hline K.Chipsona-1 & $8.16 \pm 0.01^{\mathrm{aA}}$ & $8.10 \pm 0.05^{\mathrm{aB}}$ & $8.15 \pm 0.05^{\mathrm{aA}}$ & $8.17 \pm 0.03^{\mathrm{aA}}$ \\
\hline K. Chandramukhi & $8.10 \pm 0.04^{\mathrm{bC}}$ & $8.11 \pm 0.02^{\mathrm{aBC}}$ & $8.15 \pm 0.02^{\mathrm{aA}}$ & $8.13 \pm 0.05^{\mathrm{bAB}}$ \\
\hline K.Pukhraj & $8.16 \pm 0.02^{\mathrm{aA}}$ & $8.12 \pm 0.03^{\mathrm{aB}}$ & $8.13 \pm 0.01^{\mathrm{aB}}$ & $8.17 \pm 0.01^{\mathrm{aA}}$ \\
\hline \multicolumn{5}{|c|}{ Texture } \\
\hline Control (without potato) & $8.00 \pm 0.03^{\mathrm{cB}}$ & $8.00 \pm 0.03^{\mathrm{bB}}$ & $8.03 \pm 0.03^{\mathrm{cA}}$ & $8.08 \pm 0.05^{\mathrm{cA}}$ \\
\hline \multicolumn{5}{|c|}{ Papads supplemented with different potato cultivars } \\
\hline K.Chipsona-1 & $7.65 \pm 0.01^{\mathrm{dA}}$ & $7.60 \pm 0.05^{\mathrm{cBC}}$ & $7.59 \pm 0.05^{\mathrm{dC}}$ & $7.62 \pm 0.03^{\mathrm{dB}}$ \\
\hline K. Chandramukhi & $8.30 \pm 0.04^{\mathrm{bAB}}$ & $8.31 \pm 0.02^{\mathrm{aA}}$ & $8.28 \pm 0.02^{\mathrm{bB}}$ & $8.25 \pm 0.05^{\mathrm{bC}}$ \\
\hline K.Pukhraj & $8.35 \pm 0.01^{\mathrm{aB}}$ & $8.30 \pm 0.04^{\mathrm{aC}}$ & $8.35 \pm 0.01^{\mathrm{aB}}$ & $8.39 \pm 0.02^{\mathrm{aA}}$ \\
\hline \multicolumn{5}{|c|}{ Overall acceptability } \\
\hline Control (without potato) & $7.56 \pm 0.01^{\mathrm{cA}}$ & $7.50 \pm 0.01^{\mathrm{bA}}$ & $7.53 \pm 0.04^{\mathrm{cA}}$ & $7.50 \pm 0.01^{\mathrm{cA}}$ \\
\hline \multicolumn{5}{|c|}{ Papads supplemented with different potato cultivars } \\
\hline K.Chipsona-1 & $8.11 \pm 0.02^{\mathrm{abA}}$ & $8.10 \pm 0.03^{\mathrm{aA}}$ & $8.11 \pm 0.01^{\mathrm{abA}}$ & $8.00 \pm 0.04^{\mathrm{aA}}$ \\
\hline K. Chandramukhi & $8.21 \pm 0.03^{\mathrm{aA}}$ & $8.18 \pm 0.05^{\mathrm{aA}}$ & $8.20 \pm 0.03^{\mathrm{aA}}$ & $8.12 \pm 0.05^{\mathrm{aA}}$ \\
\hline K.Pukhraj & $7.94 \pm 0.01^{\mathrm{bA}}$ & $7.96 \pm 0.01^{\mathrm{aA}}$ & $7.92 \pm 0.01^{\mathrm{bA}}$ & $7.90 \pm 0.04^{\mathrm{aA}}$ \\
\hline
\end{tabular}

Values within a column with different superscript lower case letters are significantly $(\mathrm{p}<0.05)$ different between cultivars. Values within a row with different superscript capital letters are significantly $(\mathrm{p}<0.05)$ different between storage duration. Mean values $\pm \mathrm{SD}(n=3)$

(Kaur et al., 2012; Selvamuthukumaran and Khanum, 2014). The ascorbic acid loss accounted to $17.30 \%$ after 3 months of storage period. Abong et al., (2011) and Wills and Silalahi, (1990) observed similar losses in ascorbic acid content during storage of potato crisps. During storage, a significant $(\mathrm{p}<0.05)$ decrease in total phenolic content was observed in all the potato supplemented papads, irrespective of the cultivars (Fig. 2b). The mean content of total phenolics of potato added papads was estimated to be $83.57 \mathrm{mg} \mathrm{GAE} / 100 \mathrm{~g}$ initially and this was found to decrease significantly ( $\mathrm{p}$ $<0.05$ ) to $73.31 \mathrm{mg} \mathrm{GAE} / 100 \mathrm{~g}$ after 3 months of storage at room temperature $\left(28-35^{\circ} \mathrm{C}\right)$ (Fig. 2 b). This decrease in phenolics might be due to degradation from the effect of heat, which increases with increase in storage temperature (Ezekiel et al., 2013). The change in mean total phenolics content of papads during the entire storage period from the initial values was $12.27 \%$. Selvamuthukumaran and Khanum, (2014) reported 36\% losses in total phenolics of buckwheat jam stored at $37^{\circ} \mathrm{C}$ for 8 months. Oliveira et al., (2012) also noticed higher reductions in total phenolics in pasteurized peach stored at $22^{\circ} \mathrm{C}$ for 90 days. According to Gitanjali et al. (2004), the level of phenols present in fruits and vegetables can be influenced by growing conditions, harvest conditions, species, processing methods and storage conditions.

As for processing, frying of control and potato added papads resulted in significant $(\mathrm{p}<0.05)$ losses in ascorbic acid and total phenolic content (Table 3 ). This might be due to thermoliabile nature of these compounds which resulted in their loss during frying. Similar reductions in bioactive compounds were noticed during shallow frying of raw potatoes (Gitanjali et al., 2004). The antioxidant activities for potato enriched papads as determined by scavenging DPPH radical are presented in Fig. 2c. There was slight but significant $(\mathrm{p}<0.05)$ decrease in the mean radical scavenging activities of papads during storage, regardless of cultivars (Fig. 2c). The mean radical scavenging activities of papad extracts was estimated to be $65.43 \%$ initially and this was found to decline significantly to $51.94 \%$ after 3 months of storage (Fig. 2c). The decrease in the total antioxidant 


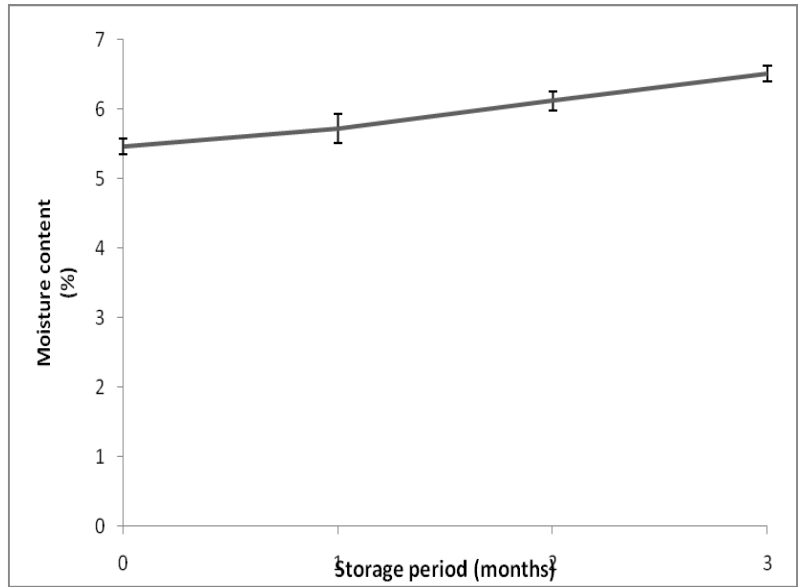

Fig. 1. Effect of storage on moisture content of potato rice papads. Mean values $\pm S D(n=3)$. Error bars represents $S D$ of the mean.

activity may be linked to decrease in the content of phytonutrients such as total phenolics and ascorbic acid. The correlation between bioactive concentration and antioxidant activity of plant foods is well established (Reyes et al., 2005; Ezekiel et al., 2013). Kapoor and Aggarwal (2014) reported significant losses (43.40\%) of total antioxidant activity in carrot juice stored at room temperature for 6 months. In our study, the loss in total antioxidant capacity as radical scavenging activity accounted for $20.62 \%$ after 3 months of storage.

A significant $(\mathrm{p}<0.05)$ decrease in antioxidant activity was found after frying of papads (Table 3 ). This could be attributed to decrease in total phenolic content, as described by Gitanjali et al. (2004).

\section{Sensory quality evaluation of papads}

It is clear from table 4 potato supplemented papads had better acceptability scores as compared to control (without potato) papads. Within the cultivars studied, color, flavor, texture and overall acceptability scores for papads supplemented with K.Chipsona-1 and K. Chandramukhi appeared to be higher than for K.Pukhraj (Table 4). Compared to K.Chipsona-1 and K.Chandramukhi papads, papads supplemented with K.Pukhraj were slightly darker in color. The lowest rating for color in K.Pukhraj conformed to high reducing sugars in this cultivar (Table 1). Color of fried potato products is the most significant visual quality criterion, which is dependent on the amount of reducing sugars in raw tubers because they induce a non enzymatic Millard reaction with free amino acids, forming unacceptable brown to black pigmented products (Ramezani and Aminlari, 2004; Kaur et al..2 2012). The range of color in potato products made from K.Chipsona-1, K.Chandramukhi and K.Pukhraj agrees with that reported by Marwaha and Sandhu, (2006) and Kaur et al. (2012). Potato papads prepared from all the three cultivars were found to be highly desirable up to 3 months of storage. Also, papads supplemented with K.Pukhraj, an unmarketable cultivar, displayed excellent keeping quality during the entire storage period (Table 4).

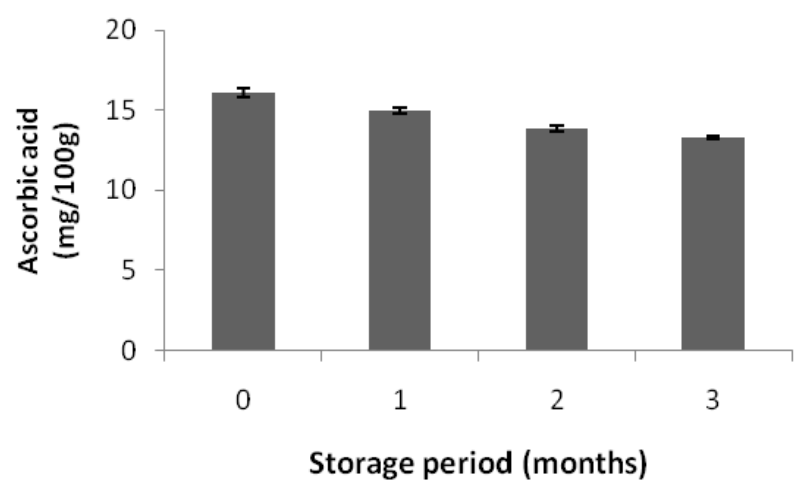

(a)

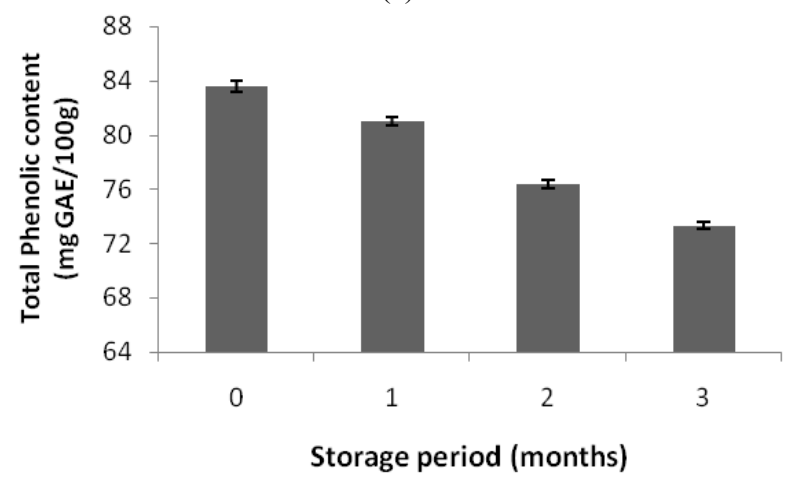

(b)

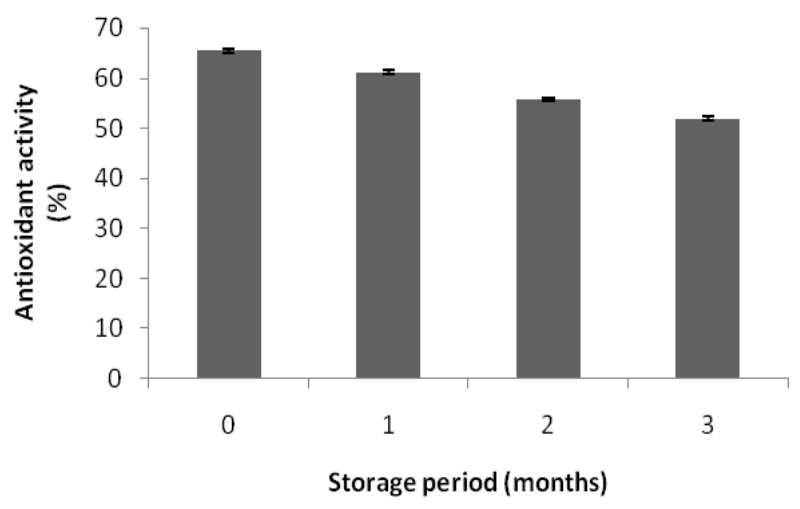

(c)

Fig. 2. Effect of storage on (a) ascorbic acid (b) total phenolic content (c) antioxidant activity of potato rice papads. Mean values $\pm S D(n=3)$. Error bars represents $S D$ of the mean

\section{Conclusion}

It can be concluded that nutritionally enriched papads (Indian cookie) can be prepared from both medium and high sugar potato (Solanum tuberosum L.) cultivars which provided significantly more bioactive compounds including ascorbic acid, total phenolics and antioxidant activity and high acceptability ratings. Incorporation of such potato cultivars into low-cost value added products such as papads could serve as an excellent vehicle for enhancing the utilization of this resourceful food crop.

\section{REFERENCES}

Abong, G.O., Okoth, M.W., Imungi, J.K. and Kabira, J.N. 
(2011). Losses of ascorbic acid during storage of fresh tubers, frying, packaging and storage of potato crisps from four Kenyan potato cultivars. Am. J. Food Technol., 6: 772 -780 .

AOAC. (2005). Official Methods of Analysis of the Association of the Official Analytical Chemists. Gaithersburg, Md.

Ezekiel, R., Singh, N., Sharma, S. and Kaur, A. (2013). Beneficial phytochemicals in potato - a review. Food Res. Int., 50: 487-496.

Garg, G. and Dahiya, S. (2003). Nutritional evaluation and shelf life studies of papads prepared from wheat-legume composite flours. Plant Foods Hum. Nutr., 58: 299-307.

Gitanjali, Devi, P.Y. and Shiva Prakash, M. (2004). Effect of shallow frying on total phenolic content and antioxidant activity in selected vegetables. J. Food Sci. Technol., 41: 666-668.

Gumul, D., Ziobro, R., Noga, M. and Sabat, R. (2011). Characterization of five potato cultivars according to their nutritional and pro-health components. Acta Sci. Pol. Technol. Aliment., 10(1): 73-81.

Jagadeesh, S.L., Hegde, L., Kotimani, S., Gorbal, K., Reddy, B.S., Swamy, G.S.K., Basavaraj, N. and Raghavan, G.S.V. (2007). Influence of packaging on storage behaviour of jackfruit papads. Bev. Food World, 34: 15-19.

Kapoor, S. and Aggarwal, P. (2014). Effect of processing and storage on bioactive compounds and antioxidant activity of carrot juice. J. Appl. Hort., 16: 80-84.

Kaur, A., Singh, N. and Ezekiel, R. (2009). Quality parameters of potato chips from different potato cultivars: Effect of prior storage and frying temperature. Int. J. Food Properties, 11: 791-803.

Kaur, S., Sandhu, K.S. and Aggarwal, P. (2012). Chlorpropham affects processing quality of potato during storage. Int. $J$. Veg. Sci., 18: 328-345.

Lachman, L. And Hamouz, K. (2005). Red and purple colored potatoes as a significant antioxidant source in human nutrition - a review. Plant Soil Environ., 51: 477-482.

Marwaha, R.S. and Pandey, S.K. (2006). Suitability of cultivars and methods for the production of dehydrated chips. Potato J., 33: 110-117.

Marwaha, R.S., Pandey, S.K., Kumar, D., Singh, S.V. and Kumar, P. (2010). Potato processing scenario in India: Industrial constraints, future projections, challenges ahead and remedies-A review. J. Food Sci. Technol., 47: 137-156.
Misra, A. And Kulshrestha, A. (2003). Effect of storage on nutritional value of potato flour made from three potato varieties. Plant Foods Hum. Nutr., 58: 1-10.

Oliveira, A., Pintado, M. and Almeida, D.P.F. (2012). Phytochemical composition and antioxidant activity of peach as affected by pasteurization and storage duration. $L W T$. -Food Sci. Technol., 49: 202-207.

Pearson, D. (1976). The chemical analysis of foods. Churchill Livingstone Edinburgh.

Puyed, S.A. and Prakash, J. (2008). Fat uptake, shelf stability and sensory quality of soy incorporated cereal based papads. Ind. J. Nutr. Dietet., 45: 176-184.

Ramezani, R. and Aminlari, M. (2004). Comparing chemical composition of four potato varieties for processing. $J$. Food Sci. Technol., 41: 689-691.

Ranganna, S. (2004). Handbook of Analysis and Quality Control for Fruit and Vegetable products. Tata McGraw Hill Publishing Company Limited, New Delhi.

Reyes, L.F., Miller, J.C. and Cisneros Zevallos, L. (2005). Antioxidant capacity, anthocyanins and total phenolics in purple and red-fleshed potato (Solanum tuberosum L.) genotypes. Am. J. Potato Res., 82: 271-277.

Saxena, R., and Mathur, P. (2013). Analysis of potato production performance and yield variability in India. Potato J., 40 (1): $38-44$.

Selvamuthukumaran, M. and Khanum, F. (2014). Processing seabuckthorn fruit for antioxidant rich jam development and shelf stability assessment. Indian J. Traditional Knowledge, 13: 335-346.

Veena, B., Reddy, B.S. and Sharan, S. (2012). Effect of incorporation of soy flour on the quality of papad. J. Bio. Agric. Healthcare, 2(5): 119-124.

Velioglu, Y.S., Mazza, G., Gho, L. and Onmah, B.D. (2009). Antioxidant activity and total phenolics in selected fruits and vegetables and grain products. J. Agric. Food Chem., 46: 4113-4117.

Wills, R.B.H. and Silalahi, J. (1990). Effect of storage temperature on loss of vitamin $\mathrm{C}$ in potato crisps. J. Sci. Food Agric., 53: 275-278.

Yamaguchi, T., Takamura, H., Mataoba, T. and Terao, J. (1998). HPLC method for evaluation of the free radical scavenging activity of foods by using 1, 1-diphenyl -picrylhydrazyl. Biosci. Biotechnol. Biochem., 62: 1201-1220. 